\title{
AKTUALISASI KEWARISAN PADA NIKAH DI BAWAH TANGAN PERSEKTIF HUKUM DI INDONESIA
}

\author{
Syarif Hidayatullah \\ Institut Agama Islam Muhammadiyah Bima \\ Email: ink.syarif@gmail.com
}

\section{Abstrak}

Persoalan kewarisan sering terjadi suatu masalah ketika berkaitan dengan jumlah serta status sebagai ahli waris, dalam sistem kewarisan di Indonesia, bahwa seseorang dapat mendapatkan warisan apabila ia memiliki kekerabatan yakni memiliki hubungan darah, serta berstatus perkawinan. Namun yang menjadi persoalan apabila perkawinan tersebut tidak memiliki status hukum yang sah secara hukum, dalam artian tidak memiliki status hukum di mata negara, hal ini mengakibatkan proses upaya seseorang dalam meminta hak nya atas kewarisannya menjadi terbatas dan malah tertutup dikarenakan tidak dimilikinya kepastian hukum bahwa ia telah mempunyai status perkawinan. Begitupun bagi kewarisan terhadap anak dari hasil perkawinan yang tidak sah tersebut atau anak hasil luar perkawinan yang dalam hukumnya hanya memiliki hubungan hukum dan kewarisan dari pihak ibu, dari hal itulah maka perlu dibahas akan persoalan yang sering hadir di masyarakat guna memperjelas status dari kewarisan dari hasil nikah di bawah tangan. 


\section{Keywords: Waris, Nikah di Bawah Tangan, Hukum, Indonesia.}

\section{Pendahuluan}

Hukum Islam memiliki peran dan kedudukan yang mulai diperhatikan dan dianut dalam sistem hukum yang ada di Indonesia, hal ini dikarenakan Pemberlakuan hukum Islam baik secara keseluruhan, maupun secara prinsip menjadi poin penting bagi sumber hukum Indonesia, terlebih hukum Islam sudah melekat dan menjadi hukum yang berlaku di masyarakat, oleh karena itu proses legislasi diperlukan guna mengkoordinir masyarakat menjadi disiplin hukum apalagi ketentuan hukumnya sudah secara umum diketahui oleh masyarakat sehingga tercipta kepatuhan hukum tanpa merusak tatanan hukum agama sebagai pemeluk dan warga negara Indonesia. ${ }^{1}$ Salah satu bentuk hukum Islam yang dianut dalam sistem hukum di Indonesia adalah hukum perkawinan. Baik dalam hal ini status dan kedudukan hukum dari perkawinan tersebut di mata hukum guna hak dan kewajiban baik dari segi syariah dan kenegaraan terpenuhi tanpa membuat salah satu pihak dirugikan.

Perkawinan merupakan jalan terbaik dan sangat dianjurkan baik dalam hukum Islam dan oleh negara dijaga guna perkawinan tersebut tidak dijadikan permainan ataupun hanya sebatas menikah tanpa diberikannya hak dan kewajiban dari pihak-pihak yang melangsungkan pernikahan tersebut, hal ini dikarenakan bukan hanya pada status akan perkawinan yang diakui namun

1 Syarif Hidayatullah, "TRANSFORMASI DAN KONTRIBUSI HUKUM ISLAM SEBAGAI SUMBER HUKUM DI INDONESIA," Jurnal Pro Justice: Kajian $\begin{array}{llllll}\text { Hukum dan Sosial 1, no. } & 2 & \text { (2019): }\end{array}$ http://ejournal.billfath.ac.id/index.php/projustice/article/view/57.

Sangaji Jurnal Pemikiran Syariah dan Hukum 
juga status anak, kewarisan serta kedudukan sepasang suami istri yang secara resmi oleh negara menjamin hak dan kewajiban guna tidak ada salah satu pihak yang dirugikan. Perkawinan dalam Undang-undang Nomor 1 Tahun 1974 tentang Perkawinan mendefinisikan sebagai ikatan lahir batin antara seorang pria dan seorang wanita sebagai suami istri dengan tujuan membentuk keluarga atau rumah tangga yang bahagia dan kekal berdasarkan Ketuhanan Yang Maha $E s a^{2}$. Sedangkan dalam kompilasi hukum Islam, mengartikan yaitu akad yang sangat kuat atau mitssaqan ghalidzan untuk mentaati perintah Allah dan melaksanakannya merupakan ibadah ${ }^{3}$.

Sah nya suatu perkawinan sebagaimana dalam Undangundang Nomor 1 Tahun 1974 tentang Perkawinan menyebutkan dalam ayat 1 dan 2 disebutkan "(1) Perkawinan adalah sah apabila dilakukan menurut hukum masing-masing agama dan kepercayaannya itu. (2) Tiap-tiap perkawinan dicatat menurut peraturan perundangundangan yang berlaku"4. Sejalan dengan Kompilasi Hukum Islam pasal 4 bahwa perkawinan dianggap "sah apabila dilakukan menurut hukum Islam sesuai dengan pasal 2 ayat (1) Undang-undang No. 1 Tahun 1974 tentang Perkawinan"5. Sedangkan dalam hukum Islam, suatu perkawinan dianggap sah apabila syarat dan rukun

2 Republik Indonesia, Undang-Undang Nomor 1 Tahun 1974 Tentang Perkawinan (Jakarta, 1974).

3 Tim Redaksi Nuansa Aulia, Kompilasi Hukum Islam: Hukum Perkawinan, Kewarisan, dan Perwakafan: disertai dengan: Undang-undang Nomor 1 Tahun 1974 Tentang Perkawinan, Undang-undang Nomor 41 Tahun 2004 Tentang Wakaf, Undang-undang Nomor 38 Tahun 1999 Tentang Penggunaan Zakat (Nuansa Aulia, 2009). 2.

4 Republik Indonesia, Undang-Undang Nomor 1 Tahun 1974 Tentang Perkawinan.

${ }^{5}$ Aulia, Kompilasi hukum Islam. 
terpenuhi, namun jika tidak terpenuhi maka perkawinan tersebut tidak sah.

\section{Nikah di Bawah Tangan}

Pernikahan berasal dari kata nikah (نكاح) yang menurut bahasa artinya mengumpulkan, saling memasukkan dan digunakan untuk arti bersetubuh (wathi) ${ }^{6}$. Sedangkan menurut istilah yaitu akad yang ditetapkan syara' untuk membolehkan bersenang-senang antara laki-laki dengan perempuan dan menghalalkan bersenang-senangnya perempuan dengan laki-laki .

Dalam Islam pernikahan bukan hanya berkaitan dengan bersenang-senang saja namun ada hal-hal lain yang mengikat, terlebih dalam konsep hukum Islam pernikahan adalah sesuatu yang sakral, terlebih dalam konteks al-Qur'an, bahwa Allah menciptakan segala sesuatu berpasang-pasangan, sebagaimana dalam surah Adz-Dzariyat (51) ayat 49:

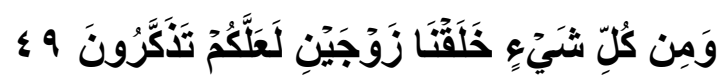

Terjemahnya:

Dan segala sesuatu Kami ciptakan berpasang-pasangan supaya kamu mengingat kebesaran Allah. ${ }^{8}$

Nikah di bawah tangan, merupakan kasus yang sudah sering terjadi di masyarakat mengingat perkawinan ini sangat sering terjadi di lingkup masyarakat terutama di Indonesia. Pernikahan ini dalam konteksnya disamakan dengan nikah sirri, hal ini

${ }^{6}$ Abdul Rahman Ghozali, Figh Munakahat (Jakarta: Kencana, 2010). 7.

7 Ibid. 8.

${ }^{8}$ QS. Adz-Dzariyat (51): 49.

Sangaji Jurnal Pemikiran Syariah dan Hukum 
dikarenakan pernikahan yang dilakukan secara sah secara hukum agama namun tidak mendapatkan pengesahan secara legal oleh negara yakni melalui lembaga KUA (Kantor Urusan Agama) yang secara hukum oleh negara diberikan kewenangan dalam mengurus urusan salah satunya pernikahan, yang jika terdaftar pada KUA, maka pernikahan tersebut dianggap sah secara negara dan hukum Islam.

\section{Kedudukan Hukum Nikah di Bawah Tangan}

Dalam hukum di Indonesia, kedudukan nikah di bawah tangan tidak diakui secara legal standing, hal ini berpedoman pada pasal 2 dalam Undang-undang Nomor 1 Tahun 1974 Tentang Perkawinan, disebutkan bahwa "(1) Perkawinan adalah sah apabila dilakukan menurut hukum masing-masing agama dan kepercayaannya itu. (2) Tiap-tiap perkawinan dicatat menurut peraturan perundangundangan yang berlaku"9. Jadi ketika suatu pernikahan yang dilakukan secara tertib secara hukum agama masing-masing namun tidak memenuhi syarat administrasi secara negara yakni tidak dicatat sesuai perundang-undangan dimana diharuskan dalam proses perkawinan dilakukan di Kantor Urusan Agama, maka pernikahan tersebut tidak diakui dan tidak memiliki kekuatan hukum secara negara akan sah nya perkawinan tersebut.

Senada dengan keputusan fatwa Majelis Ulama Indonesia (MUI) Nomor 10 Tahun 2008 Tentang Nikah Di Bawah Tangan dalam penetapan hukumnya menyatakan: ${ }^{10}$

9 Republik Indonesia, Undang-Undang Nomor 1 Tahun 1974 Tentang Perkawinan.

10 Majelis Ulama Indonesia Komisi Fatwa, "FATWA MAJELIS ULAMA INDONESIA Nomor 10 Tahun 2008 Tentang NIKAH DI BAWAH TANGAN" 
1. Pernikahan Di bawah Tangan hukumnya sah karena telah terpenuhi syarat dan rukun nikah, tetapi haram jika terdapat madharrat.

2. Pernikahan harus dicatatkan secara resmi pada instansi berwenang, sebagai langkah preventif untuk menolak dampak negative/madharrat (saddan lidz-dzari'ah).

Dari hasil fatwa tersebut terlihat bahwa nikah di bawah tangan, tidak memberikan suatu manfaat bagi salah satu pihak, yakni perempuan dan anak dari hasil pernikahan tersebut, hal ini dikarenakan status perkawinan yang tidak diakui secara hukum negara mengakibatkan baik anak dan istri tidak diakui oleh negara bahwa telah dilangsungkan perkawinan antara pihak tersebut. Dari hal itulah maka pernikahan di bawah tangan tidak anjurkan, namun jika pernikahan tersebut tidak memenuhi syarat dan rukun nikah, maka haram untuk dilaksanakan, seperti nikah mut'ah.

Dalam hukum perkawinan, terutama dalam hukum Islam, suatu perkawinan dianggap sah secara hukum Islam harus memenuhi syarat dan rukun perkawinan, hal ini sebagaimana hukum nya yakni syarat-syarat adalah: ${ }^{11}$

1. Calon Suami, syarat-syaratnya: ${ }^{12}$

a. Beragama Islam

b. Laki-laki

(Majelis Ulama Indonesia Komisi Fatwa, September 17, 2008), https://mui.or.id/produk/fatwa/1037/nikah-di-bawah-tangan/.

11 Ibnu Mas'ud and Zaenal Abidin, Fiqih Mazhab Syafi'I Buku 2: Muamalat, Munakahat, Jinayat, 2nd ed. (Bandung: Pustaka Setia, 2007). 268.

12 Amiur Nurudin and Azhari Akmal Tarigan, Hukum Perdata Islam di Indonesia Studi Kritis Perkembangan Hukum Islam dari Fikih, UU No. 1/1974 Sampai KHI (Jakarta: Kencana, 2014). 62-63.

Sangaji Jurnal Pemikiran Syariah dan Hukum 
c. Jelas orangnya

d. Tidak terdapat halangan perkawinan

2. Calon Istri, syarat-syaratnya: ${ }^{13}$

a. Beragama Islam

b. Perempuan

c. Jelas orangnya

d. Tidak terdapat halangan perkawinan

3. Wali, syarat-syaratnya: ${ }^{14}$
a. Laki-laki
b. Dewasa
c. Mempunyai hak perwalian
d. Tidak terdapat halangan perwaliannya

4. Saksi Nikah, syarat-syaratnya: ${ }^{15}$
a. Minimal dua orang laki-laki
b. Hadir dalam ijab qabul
c. Dapat mengerti maksud akad
d. Islam
e. Dewasa

5. Ijab Qabul, syarat-syaratnya: ${ }^{16}$
a. Adanya pernyataan mengawinkan dari wali
b. Adanya pernyataan penerimaan dari calon mempelai
c. Memakai kata-kata nikah, tazwij atau terjemahan dari kedua akta tersebut
d. Antara ijab dan qabul bersambungan
e. Antara ijab dan qabul jelas maksudnya
13 Ibid.
14 Ibid.
15 Ibid.
16 Ibid. 
f. Orang yang terkait dengan ijab dan qabul tidak sedang ihram haji dan umrah

g. Majlis ijab dan qabul itu harus dihadiri minimum empat orang yaitu calon mempelai atau wakilnya, wali dari mempelai wanita dan dua orang saksi.

Persoalan nikah di bawah tangan tidak hanya berkaitan pada persoalan status hukum atas perkawinan tersebut namun juga mengikat pada pasangan tersebut, baik dari status suami istri dalam hal ini hak dan kewajibannya, dan anak nantinya yang berimbas pada hukum terkait status anak dan kewarisan. Semua itu menjadi pertimbangan dalam melihat bagaimana imbas dari nikah di bawah tangan.

Keharusan dalam pencatatan perkawinan sebagaimana dalam Undang-undang No. 1 Tahun 1974 Tentang Perkawinan dalam pasal 2, dalam aturan pelaksanaannya, yakni dalam Peraturan Pemerintah Nomor 9 Tahun 1975 Tentang Pelaksanaan Undangundang Nomor 1 Tahun 1974 Tentang Perkawinan, hal ini terlihat pada pasal 10 ayat 2 dan 3 dalam Bab Tata Cara Perkawinan, disebutkan:

"Tata cara perkawinan dilakukan menurut hukum masing-masing agamanya dan kepercayaannya itu; Dengan mengindahkan tata cara perkawinan menurut masing-masing hukum agamanya dan kepercayaannya itu, perkawinan dilaksanakan dihadapan Pegawai Pencatat dan dihadiri oleh dua orang saksi"17

17 Republik Indonesia, Peraturan Pemerintah Nomor 9 Tahun 1975 Tentang Pelaksanaan Undang-undang Nomor 1 Tahun 1974 Tentang Perkawinan (Jakarta, 1975).

Sangaji Jurnal Pemikiran Syariah dan Hukum 
Selanjutnya pada pasal 11 nya memberikan kejelasan akan proses perkawinan dan status perkawinan tersebut: ${ }^{18}$

(1) Sesaat sesudah dilangsungkannya perkawinan sesuai dengan ketentuan-ketentuan Pasal 10 Peraturan Pemerintah ini, kedua mempelai menandatangani akta perkawinan yang telah disiapkan oleh Pegawai Pencatat berdasarkan ketentuan yang berlaku.

(2) Akta perkawinan yang telah ditandatangani oleh mempelai itu, selanjutnya ditandatangani pula oleh kedua saksi dan Pegawai Pencatat yang menghadiri perkawinan dan bagi yang melangsungkan perkawinan menurut agama Islam, ditandatangani pula oleh wali nikah atau yang mewakilinya.

(3) Dengan penandatanganan akta perkawinan, maka perkawinan telah tercatat secara resmi.

Dalam pasal tersebut disebutkan adanya Akta perkawinan. Akta menjadikan alat bukti yang sangat otentik adakan adanya tindakan hukum yakni perkawinan antara laki-laki dan perempuan yang diakui secara hukum dan secara agama. Melalui pencatatan perkawinan yang dibuktikan dengan akta nikah, apabila terjadi perselisihan di antara suami isteri, atau salah satu pihak tidak bertanggung jawab, maka yang lain dapat melakukan upaya hukum guna mempertahankan atau memperoleh haknya masing-masing, karena dengan akta nikah suami isteri memiliki bukti otentik atas perkawinan yang terjadi antara mereka. ${ }^{19}$

18 Ibid.

19 "Fatwa Tarjih Tentang Nikah Sirri I Suara Muhammadiyah," last modified May 21, 2016, accessed April 25, 2021, https://suaramuhammadiyah.id/2016/05/22/fatwa-tarjih-tentang-nikah-sirri/. 


\section{Sistem Kewarisan di Indonesia}

Kewarisan sendiri dalam pengertiannya sebagaimana dalam pasal 171 Kompilasi Hukum Islam, disebutkan: ${ }^{20}$

Hukum kewarisan adalah hukum yang mengatur tentang pemindahan hak pemilikan harta peninggalan (tirkah) pewaris, menentukan siapa-siapa yang berhak menjadi ahli waris dan berapa bagiannya masing-masing.

Dari pengertian di atas dapat dipahami bahwa sistem kewarisan dalam perspektif kompilasi hukum Islam tetap mengacu pada konsep kewarisan Islam secara umum, karena memang sistem kewarisan yang berlaku di Indonesia salah satunya menggunakan sistem kewarisan Islam, selain kewarisan adat.

Hukum sistem kewarisan yang berlaku di Indonesia, sampai sekarang masih beraneka ragam dan masih belum mempunyai kesatuan hukum yang dapat diterapkan secara umum. Hal ini dikarenakan hukum akan mengikuti status dari akibat hukum yang diterapkan terutama sasaran pemberlakuan hukum. Keanekaragaman hukum waris tersebut dapat dilihat dari adanya pembagian hukum waris serta bagian dan status hukum tersebut. ${ }^{21}$ Dalam sistem hukum waris di Indonesia, terkait pembagian waris yang diatur di beberapa sumber hukum diantaranya:

1. Hukum waris yang terdapat pada Kompilasi Hukum Islam (KHI)

${ }^{20}$ Aulia, Kompilasi hukum Islam. 53-54.

21 Yusuf Somawinata, "HUKUM KEWARISAN DALAM KOMPILASI HUKUM ISLAM (KHI) DI INDONESIA," ALQALAM 26, no. 1 (April 30, 2009): 129.

Sangaji Jurnal Pemikiran Syariah dan Hukum 
Dalam sistem kewarisan dalam kompilasi hukum Islam terdapat asas-asas kewarisan, antara lain:

a. Asas Ijbari

Dalam konsep ini sama seperti dalam konsep kewarisan Islam, yakni peralihan harta dari seseorang yang telah meninggal dunia (muwaris) kepada ahli warisnya. Hal ini sesuai dengan pengertian yang dijelaskan pada pasal 171 kompilasi hukum Islam.

b. Asas Bilateral

Asas bilateral ini tidak jauh berbeda dengan konsep kewarisan dalam hukum Islam, yaitu dalam kewarisan mengandung arti bahwa harta kewarisan beralih kepada atau melalui dua arah, yaitu hak kewarisan dari kedua belah pihak, baik dari pihak kerabat garis keturunan laki-laki dan pihak kerabat garis keturunan perempuan. ${ }^{22} \mathrm{Hal}$ ini bisa dilihat pada pasal 174 dan pasal 185 kompilasi hukum Islam.

c. Asas Ahli Waris Langsung dan Ahli Waris Pengganti

Yang menjadikan sistem kewarisan di Kompilasi Hukum Islam menarik adalah adanya asas kewarisan ahli waris pengganti yang dijabarkan dalam pasal 185 kompilasi hukum Islam: ${ }^{23}$

(1) Ahli waris yang meninggal lebih dahulu dari pada sipewaris maka kedudukannya dapat digantikan oleh anaknya, kecuali mereka yang tersebut dalam Pasal 173.

(2) Bagian ahli waris pengganti tidak boleh melebihi dari bagian ahli waris yang sederajat dengan yang diganti.

22 Amir Syarifuddin, Hukum Kewarisan Islam (Jakarta: Kencana, 2012). 22.

${ }^{23}$ Aulia, Kompilasi hukum Islam. 58. 
Dalam sistem hukum kewarisan yang berlaku di Indonesia, sebab-sebab seseorang dapat saling mewarisi, antara lain:

a. Hubungan Kekerabatan

Adanya hubungan kekerabatan ditentukan oleh adanya hubungan darah yang ditentukan pada saat adanya kelahiran. Dalam menemukan hubungan atas kelahiran tentu berawal dari adanya hubungan pernikahan sehingga melahirkan seorang bayi dan secara langsung akan memiliki hubungan kekerabatan baik dari Ibu dan Ayahnya. Dalam hubungan kekerabatan tersebut dapat dikatakan memiliki hubungan apabila akad nikah sah secara hukum. ${ }^{24}$

b. Hubungan Perkawinan

Selain hak kewarisan berlaku atas dasar hubungan kekerabatan, hak kewarisan juga berlaku atas dasar hubungan perkawinan, dalam artian bahwa suami ahli waris bagi isterinya yang meninggal dan isteri ahli waris bagi suaminya yang meninggal. ${ }^{25}$

Berlakunya hubungan kewarisan antara suami dan isteri didasarkan pada dua ketentuan, pertama, antara keduanya telah berlangsung akad nikah yang sah, ini berarti bahwa perkawinan orang-orang yang beragama Islam dikatakan sah, bila menurut hukum Islam perkawinan tersebut adalah sah. Kedua, berkenaan dengan hubungan kewarisan disebabkan oleh hubungan perkawinan ialah

24 Syarifuddin, Hukum Kewarisan Islam. 177-178.

${ }^{25}$ Ibid. 190

Sangaji Jurnal Pemikiran Syariah dan Hukum 
bahwa suami dan isteri masih terikat dalam tali perkawinan saat salah satu pihak meninggal dunia. ${ }^{26}$

Sedangkan dalam besaran bagian bagi pewaris dalam dilihat pada Bab III Besarnya Bahagian dari pasal 176 sampai dengan pasal 182, yakni: ${ }^{27}$

(Pasal 176) Anak perempuan bila hanya seorang ia mendapat separuh bagian, bila dua orang atau lebih mereka bersama-sama mendapat dua pertiga bagian, dan apabila anak perempuan bersama-sama dengan anak laki-laki, maka bagian anak laki-laki adalah dua berbanding satu dengan anak perempuan.

(Pasal 177) Ayah mendapat sepertiga bagian bila pewaris tidak meninggalkan anak, bila ada anak, ayah mendapat seperenam bagian.

Pasal 178 - (1) Ibu mendapat seperenam bagian bila ada anak atau dua saudara atau lebih. Bila tidak ada anak atau dua orang saudara atau lebih, maka ia mendapat sepertiga bagian. (2) Ibu mendapat sepertiga bagian dari sisa sesudah diambil oleh janda atau duda bila bersama-sama dengan ayah.

(Pasal 179) Duda mendapat separuh bagian, bila pewaris tidak meninggalkan anak, dan bila pewaris meninggalkan anak, maka duda mendapat seperempat bagian.

(Pasal 180) Janda mendapat seperempat bagian bila pewaris tidak meninggalkan anak, dan bila pewaris meninggalkan anak maka janda mendapat seperdelapan bagian.

(Pasal 181) Bila seorang meninggal tanpa meninggalkan anak dan ayah, maka saudara laki-laki dan saudara perempuan seibu

26 Ibid. 191-193

27 Aulia, Kompilasi hukum Islam. 56-57. 
masing-masing mendapat seperenam bagian. Bila mereka itu dua orang atau lebih maka mereka bersama-sama mendapat sepertiga bagian.

(Pasal 182) Bila seorang meninggal tanpa meninggalkan anak dan ayah, sedang ia mempunyai satu saudara perempuan kandung atau seayah, maka ia mendapat separuh bagian. Bila saudara perempuan tersebut bersama-sama dengan saudara perempuan kandung atau seayah dua orang atau lebih, maka mereka bersamasama mendapat dua pertiga bagian. Bila saudara perempuan tersebut bersama-sama dengan saudara laki-laki kandung atau seayah, maka bagian saudara laki-laki dua berbanding satu dengan saudara perempuan.

Sedangkan bagian ahli waris anak di luar nikah, hanya mempunyai hubungan kewarisan pada pihak Ibunya saja, tidak dengan ayahnya. Sebagaimana dijabarkan pada pasal 186 kompilasi hukum Islam: ${ }^{28}$

Anak yang lahir di luar perkawinan hanya mempunyai hubungan saling mewaris dengan ibunya dan keluarga dari pihak ibunya.

2. Hukum waris yang terdapat dalam Kitab Undang-undang Hukum Perdata (KUHP /BW'), Buku 1 Bah XII s.d. XVIII dari pasal 830 s.d. pasal 1130. Dalam sistem kewarisan Perdata, seorang ahli waris terdapat tiga pilihan, yakni menerima penuh, menolak atau menerima warisan dengan syarat ${ }^{29}$, yang mana berbeda dengan hukum Islam yang terdapat asas Ijbariyah, yang bersifat memaksa. Sedangkan dalam hal kewarisan terkait anak lahir di luar pernikahan dan tidak

${ }^{28}$ Republik Indonesia, Inpres Nomor 1 Tahun 1991 tentang Kompilasi Hukum Islam (Jakarta, 1991).

${ }^{29}$ Subekti, Pokok-pokok Hukum Perdata (P.T. Intermasa, 1978). 105. 
diakui maka ia tidak mendapatkan warisan, namun apabila anak di luar perkawinan tersebut diakui (erkend natuutlijk) maka bagian yang didapatkan tergatung dari adanya beberapa anggota keluarga yang $\operatorname{sah}^{30}$.

3. Hukum waris yang terdapat dalam hukum adat yaitu dalam bagian hukum waris adat; dan

4. Hukum waris yang terdapat dalam hukum waris Islam, yaitu ketentuan hukum waris dalam fiqh Islam, yang disebut Mawarits atau ilmu Faraidh. Dalam pembagian ataupun ukurannya tidak jauh beda dengan Kompilasi Hukum Islam, hal ini karena Kompilasi Hukum Islam merujuk dalam sistem kewarisan Islam.

\section{Kedudukan Kewarisan Terkait Nikah di Bawah Tangan}

Dalam pemberlakuan hukum waris, terdapat hal yang penting yakni kepastian dalam hukum akan status perkawinan serta kekerabatan terutama anak yang lahir di luar perkawinan. Sampai saat ini, ketetapan akan pentingnya sah nya sebuah perkawinan sangat diperlukan mengingat buku nikah yang menjadi bukti otentik yang penting dalam pembuktian akan telah terjadinya suatu perkawinan sehingga seorang anak dapat nantinya mendapatkan kewarisan dari ayah, bukan lagi pada lingkup turunan Ibu, begitupun istri yang dapat menuntut hak dan kewajibannya terhadap suaminya apabila suami tidak memberikan hak-hak nya pada saat perkawinan.

Persoalan ini masih saja terulang, hal ini dikarenakan masih kurangnya kesadaran hukum masyarakat akan pentingnya

${ }^{30}$ Ibid. 100. 
pencatatan perkawinan. Yang secara hukum sangat diperlukan namun sebagian pihak merasa tidak perlu dengan pertimbanganpertimbangan yang masih tidak mau terbuka dalam pemikirannya, atau memang adanya kesengajaan yang dilakukan oleh pihakpihak guna menjaga dari izin yang dirasa memberatkan, hal ini dapat dicontohkan yakni poligami, yang secara hukum harus adanya izin tertulis dari istri pertama ketika akan dilangsungkan pernikahan kedua lewat persetujuan izin poligami di Pengadilan Agama.

Ketika syarat-syarat agar dapatnya saling mewarisi tidak terpenuhi, yakni status kekerabatan dan perkawinan, maka kewarisan tersebut tidak dapat dilakukan apalagi ketika perkawinan tersebut berstatus nikah di bawah tangan yang memang tidak dicatatkan maka ia tidak mendapatkan status hukum, dan dianggap sebagai pernikahan yang ilegal. Terlebih di masyarakat sekarang ketika adanya pernikahan di bawah tangan memberikan kesan negatif akan status dari pernikahan tersebut, yang terkadang dianggap nikah liar ataupun nikah ilegal, dan itu memberikan beban psikis bagi kehidupan perkawinannya terutama anak yang nanti akan bergaul dengan masyarakat.

Dalam sistem hukum di Indonesia memberikan peluang dalam status perkawinan, yakni ketika perkawinan tidak dicatatkan maka perkawinan tersebut dapat diajukan ke Pengadilan Agama guna dilakukan Isbat Nikah, maksudnya pernikahan tersebut dilakukan ulang di depan Pengadilan Agama guna mendapatkan status sah secara hukum. Begitupun status anak di luar nikah sebagaimana putusan Mahkamah Konstitusi No. 46/PUU-VIII/2010 tanggal 17 Februari 2012 menyatakan bahwa 
Pasal 43 ayat (1) UU No. 1 Tahun 1974 tentang Perkawinan (“UU Perkawinan") bertentangan dengan UUD 1945 bila tidak dibaca:

Dalam amarnya menyebutkan:

Anak yang dilahirkan di luar perkawinan hanya mempunyai hubungan perdata dengan ibunya dan keluarga ibunya serta dengan laki-laki sebagai ayahnya yang dapat dibuktikan berdasarkan ilmu pengetahuan dan teknologi dan/atau alat bukti lain menurut hukum mempunyai hubungan darah, termasuk hubungan perdata dengan keluarga ayahnya.

Tujuan dari MK adalah untuk menegaskan bahwa anak luar kawin pun berhak mendapat perlindungan hukum. Menurut pertimbangan $\mathrm{MK}$, hukum harus memberi perlindungan dan kepastian hukum yang adil terhadap status seorang anak yang dilahirkan dan hak-hak yang ada padanya, termasuk terhadap anak yang dilahirkan meskipun keabsahan perkawinannya masih disengketakan. ${ }^{31}$

\section{Simpulan}

Konteks nikah di bawah tangan sekarang masih mengalami kesenjangan akan pentingnya pernikahan tersebut dicatatkan guna dapat mengakomodir terkait kewarisan. Terlebih dalam sistem kewarisan tersebut memerlukan syarat agar dapat seseorang tersebut mendapatkan bagian waris sebagaimana ketentuan hukum yang berlaku, yakni adanya hubungan kekerabatan dan perkawinan. Yang memang dalam perkawinan diperlukannya

31 "Ulasan lengkap: Hubungan Perdata Anak Luar Kawin dengan Ayahnya Pasca-Putusan MK," hukumonline.com/klinik, accessed April 25, 2021, https://www.hukumonline.com/klinik/detail/ulasan/lt4f7ae93da9a23/hubunganperdata-anak-luar-kawin-dengan-ayahnya-pasca-putusan-mk/. 
status akan sah nya perkawinan. Dalam Kompilasi Hukum Islam, terdapat upaya hukum yang dapat dipertimbangkan hakim ketika persoalan kewarisan ini masuk pada ranah peradilan, yakni masih adanya ruang untuk diberikan upaya wasiat wajibah bagi anak di luar perkawinan, guna mendapatkan porsi warisan terhadap ayahnya, begitu juga dengan upaya tes DNA agar memastikan status hubungan darah antara anak dengan orang tua nya. Namun yang menjadi persoalan, hukum yang terkait dengan kewarisan tetap menjunjung tinggi akan ketentuan yang berlaku tentang syarat-syarat tersebut. Maka tentu perlu dilakukannya pemberian pemahaman hukum tentang pentingnya pencatatan perkawinan, terlebih dalam sistem hukum di Indonesia memberikan peluang untuk perbaikan akan status tidak sah nya perkawinan di bawah tangan tersebut, yakni dilakukannya isbat nikah, begitupun status anak dengan dibuktikan tes DNA akan kecocokan DNA antara anak dan si Ayah guna anak tersebut mendapatkan waris akan orang tua nya sendiri sesuai putusan Mahkamah Konstitusi No. 46/PUU-VIII/2010 tanggal 17 Februari 2012.

Sangaji Jurnal Pemikiran Syariah dan Hukum 


\section{Daftar Pustaka}

Aulia, Tim Redaksi Nuansa. Kompilasi Hukum Islam: Hukum Perkawinan, Kewarisan, dan Perwakafan: disertai dengan: Undang-undang Nomor 1 Tahun 1974 Tentang Perkawinan, Undang-undang Nomor 41 Tahun 2004 Tentang Wakaf, Undang-undang Nomor 38 Tahun 1999 Tentang Penggunaan Zakat. Nuansa Aulia, 2009.

Ghozali, Abdul Rahman. Fiqh Munakahat. Jakarta: Kencana, 2010. Hidayatullah, Syarif. “TRANSFORMASI DAN KONTRIBUSI HUKUM ISLAM SEBAGAI SUMBER HUKUM DI INDONESIA." Jurnal Pro Justice: Kajian Hukum dan Sosial 1, no. $\quad 2 \quad$ (2019): 9

http://ejournal.billfath.ac.id/index.php/projustice/article/vie $\mathrm{w} / 57$.

Komisi Fatwa, Majelis Ulama Indonesia. "FATWA MAJELIS ULAMA INDONESIA Nomor 10 Tahun 2008 Tentang NIKAH DI BAWAH TANGAN." Majelis Ulama Indonesia Komisi Fatwa, September 17, 2008. https://mui.or.id/produk/fatwa/1037/nikah-di-bawahtangan/.

Mas'ud, Ibnu, and Zaenal Abidin. Fiqih Mazhab Syafi'I Buku 2: Muamalat, Munakahat, Jinayat. 2nd ed. Bandung: Pustaka Setia, 2007.

Nurudin, Amiur, and Azhari Akmal Tarigan. Hukum Perdata Islam di Indonesia Studi Kritis Perkembangan Hukum Islam dari Fikih, UU No. 1/1974 Sampai KHI. Jakarta: Kencana, 2014.

Republik Indonesia. Inpres Nomor 1 Tahun 1991 tentang Kompilasi Hukum Islam. Jakarta, 1991.

- - - Peraturan Pemerintah Nomor 9 Tahun 1975 Tentang Pelaksanaan Undang-undang Nomor 1 Tahun 1974 Tentang Perkawinan. Jakarta, 1975. 
- - - . Undang-Undang Nomor 1 Tahun 1974 Tentang Perkawinan. Jakarta, 1974.

Somawinata, Yusuf. "HUKUM KEWARISAN DALAM KOMPILASI HUKUM ISLAM (KHI) DI INDONESIA." ALQALAM 26, no. 1 (April 30, 2009): 129.

Subekti. Pokok-pokok Hukum Perdata. P.T. Intermasa, 1978.

Syarifuddin, Amir. Hukum Kewarisan Islam. Jakarta: Kencana, 2012.

"Fatwa Tarjih Tentang Nikah Sirri I Suara Muhammadiyah." Last modified May 21, 2016. Accessed April 25, 2021. https://suaramuhammadiyah.id/2016/05/22/fatwa-tarjihtentang-nikah-sirri/.

"Ulasan lengkap: Hubungan Perdata Anak Luar Kawin dengan Ayahnya Pasca-Putusan MK." hukumonline.com/klinik. Accessed April 25, 2021. https://www.hukumonline.com/klinik/detail/ulasan/lt4f7ae9 3da9a23/hubungan-perdata-anak-luar-kawin-denganayahnya-pasca-putusan-mk/.

Sangaji Jurnal Pemikiran Syariah dan Hukum 